the report into medical, social, and those related to the law, and further categorised into those associated with intoxication (for example, alcoholic poisoning, head injury, drug overdose, domestic violence, child neglect and abuse, absenteeism, road traffic accidents, drinking and driving, homicide) excessive use (fatty liver, cardiomyopathy, memory impairment, cancers of the mouth, throat, and gullet, financial difficulties, divorce, homelessness, habitual convictions for drunkenness), and dependency (anxiety, epilepsy, delirium tremens, personality change, fraud). Wherever possible numbers are put on these associations, and this categorisation is very effective in bringing home the tremendous breadth and depth of problems associated with alcohol-and the report does not confuse causation and association. The report puts the total cost to Britain of alcohol misuse conservatively at $£ 1000 \mathrm{~m}$; a study published in the March issue of the British Fournal of Addiction suggests an even higher figure of $£ 1500 \mathrm{~m}$ (1983 prices). ${ }^{13}$

This important but brief chapter should drive the report's readers on to their own chapters anxious to see what they can do to help-for there are then detailed recommendations for each group. The longest section is that devoted to the National Health Service, but the other sections address the government, the Scottish Office, the Scottish Home and Health Department, the Scottish Education Department, the health boards, the local authorities, the educational services, the Health and Safety Executive, voluntary bodies, trade unions, employers' associations, the media, and the courts. The recommendations addressed to the NHS include a six part policy for the use of alcohol on NHS premises, and an impression of the detail of the report can be gained by noting that there are nine specific recommendations for senior hospital medical staff, seven for the professional bodies of general practitioners as well as four for the primary health care team, and 12 for area health education officers.

But perhaps the one group that needs to read this report more closely than any other are the members of the Department of Health and Social Security in London, for surely England deserves such a report. The excuse that Scotland's alcohol problems are appreciably worse than those south of the border is no longer valid,,$^{14}$ and to bleat that these exercises are easier in small countries would be to admit defeat even before starting. England, Wales, and Northern Ireland should all have reports as impressive as this one from Scotland, and what all need even more is action along the lines suggested in the Scottish report.

1 Scottish Health Education Coordinating Committee. Health education in the prevention of alcohol related problems. Edinburgh: Scottish Home and Health Department, 1985. (Copies ar available from the Scottish Health Education Coordinating Committee, St Andrew's House, Edinburgh EH1 3DE 0315568501 ext 2438

Veitch A. Minister clashes with BMA on alcohol. Guardian 1984 November $29 \cdot 4$

Special Committee of the Royal College of Psychiatrists. Alcohol and alcoholism. London: Tavistock Publications 1979 .

World Health Organisation Expert Committee. Problems related to alcohol consumption. Geneva: WHO, 1979 .

5 House of Commons Expenditure Committee. Report on preventive medicine, London: HMSO, 1977.

6 Bruun K. Alcohol policies in the United Kingdom. Stockholm: Sociologiska Institutionen, 1982.

Department of Health and Social Security Advisory Committee on Alcoholism. Kiport on prevention. London: HMSO, 1978

8 Department of Health and Social Security. Prevention and health: drinking sensibly. London: HMSO, 1981.

9 Robertson I, Hodgson R, Orford J, McKechnie R. Psychology and problem drinking. Report of a working party convened by the British Psychological Society division of clinical psychology. Leicester: BPS, 1984

10 Anonymous. Drink. Which? 1984 ; October:445-9.

11 Scottish Health Services Planning Council. Scottish health authorities' priorities for the eighties. Edinburgh: Scottish Home and Health Department, 1980.

12 Kendell RE. The beneficial consequences of the United Kingdom's declining per capita consumption of alcohol in 1979-82. Alcohol and Atcoholism 1984;19:271-6.

13 McDonnell R, Maynard A. The costs of alcohol misuse. Brf Addict 1985;80:27-35.

14 Latcham RW, Kreitman N, Plant MA, Crawford A. Regional variations in British alcoho morbidity rates: a myth uncovered? I Clinical surveys. Br Med $\mathcal{f}$ 1984;289:1341-3.

15 Crawford A, Plant MA, Kreitman N, Latcham RW. Regional variations in British alcohol morbidity rates: a myth uncovered? II Population surveys. Br Med $\mathcal{f}$ 1984;289:1343-5.

\section{Family practitioner committees: a price for independence?}

The conflict between the government and the profession over the limited list has overshadowed an important change in the organisation of the NHS. On 1 April family practitioner committees in England and Wales become autonomous authorities, independent of district health authorities and directly accountable to the Department of Health and Social Security. The aims of this independence, as seen by the government, are: to improve primary care; to strengthen the planning of local health care (in concert with district health authorities) and the collaboration between family practitioner committees and other services provided by local government; to improve the committees' administrative efficiency; and to make them more accountable to the DHSS. Above all the government is seeking greater value for money from the primary care sector. It will use the new arrangements for family practitioner committee accountability to achieve this. But as might be expected nowadays the new committees will receive no extra funds from the DHSS with which to discharge their wider responsibilities in planning, etc.

Independence was achieved only after a long struggle by the profession against considerable odds. The Society of Family Practitioner Committees and the BMA's General Medical Services Committee were almost alone in pressing for legislation to implement this change. The governmenttogether with many other powerful bodies, including the other political parties-were not convinced that family practitioner committees should be hived off from the district health authorities. There were doubts about whether independence would undermine cooperation at the local level between family practitioner committees and district health authorities and whether autonomous family practitioner committees would exercise sufficient "control" over the contractor professions-general practitioners, dentists, pharmacists, and opticians. Those who favoured independence saw the new status as a vital catalyst for change; the standing of primary care within the NHS would be enhanced by putting it on an equal administrative footing with the hospital sector. Any changes, however, must not prejudice the committees' duties on "pay, rations, and discipline," which have been an essential responsibility in the running of the primary care service.

Since the idea of independence was originally mooted other-largely unforeseen-developments have occurred that will undoubtedly affect the style of the new autonomous family practitioner committees. It is already apparent that family practitioner committees are acquiring new executive teeth. Doctors have already seen their influence wane in the forum of the Society of Family Practitioner Committees. A new generation of family practitioner committee chairmen and lay and professional members have been hand picked by ministers. Indeed, ministers have insisted on personally selecting from the nominees of local medical committees those doctors who fill the professional seats on the family practitioner committees, and in some areas local medical committee chairmen and secretaries have not been reappointed, a loss of experience the committees can ill afford.

Undoubtedly family practitioner committees across the country will appear to be "under new management," and this signals the end of what some outsiders saw as a too cosy relationship. The influence of the profession may be weakened 
and the well tried principle of partnership that has always guided the affairs of family practitioner committees may be at risk. The flavour of some new lay appointments to family practitioner committees has been decidedly party politicalnot a new phenomenon but not one the profession wants to see extended. Furthermore, in many areas so few of the former members have been reappointed that continuity is seriously at risk, a particular drawback in medical service committees, where experienced members are essential if complaints by patients are to be fairly and expeditiously dealt with. Alongside these changes in membership the introduction of more rigorous financial and accounting arrangements between family practitioner committees and the DHSS will encourage them to be more thorough and assertive in their search to secure value for money. ${ }^{1}$ A tougher approach to policing the contracts of the professions is already apparent. At the same time there is greater emphasis on a wider public accountability. The wish to see a stronger local consumer voice in defining the aims and policies of family practitioner services accords with this government's declared commitment to consumerism.

Has family practitioner committee independence merely set a stage for introducing other more radical changes in general practice? Speculation is rife about the promised Green Paper on general practice, with rumours that at least three different versions are circulating around Whitehallone of which may have been influenced by the Prime Minister herself. Press reports have suggested that ministers are favourably disposed towards the experimental scheme for private general practice provided by the Harrow Health Care Centre, and that serious thought has been given to the introduction of a voucher scheme into NHS general practice (though this has been quickly denied by the Secretary of State), again in the cause of competition and consumerism.

The most worrying aspect of the rumours is their nature rather than their actual content, for they will remind doctors of Westminster's penchant for panaceas. Politicians search for easy and readily achievable solutions to complex issues and for ideological levers that can be pulled to provide quick remedies. One obvious example is the use of cash limits as a monetarist tool both to contain inflation and to reduce government spending. A major danger facing general practice is that politicians and civil servants are thrashing around for a simple remedy to contain costs and make it more accountable to Whitehall, conveniently ignoring the complexities of this branch of medical care.

The profession has a daunting educational task on its hands. Politicians will need reminding (yet again) that Britain has one of the most cost effective and comprehensive primary care systems in the world, the envy of other developed countries. ${ }^{2}$ One reason for this is Britain's facility for compromise: in this instance the ability to combine the entrepreneurial talents of independently employed general practitioners with the logistical and financial strengths of a nationalised health service. It would be a tragedy if a government dedicated to the entrepreneurial ideal were to destroy this valuable and effective compromise. By thoughtlessly applying its ideological precepts the government could too easily inflict lasting damage on general practice.

If they are wise ministers will allow the newly independent family practitioner committees to run themselves in before advocating further changes in general practice. For the Green Paper to be of help to patients and general practitioners it will need to be carefully prepared, to contain a wide range of options, and to be given ample time for widespread discussion. For in proposing any subsequent changes in primary care the politicians must have not only the support of the public but also the confidence of the profession.

\footnotetext{
1 Ellis N. Family practitioner committee independence: what will it mean? $\operatorname{Br}$ Med $\mathcal{J}$ 1985;290: $607 \cdot 11$.

General Medical Services Committee. The cost effectiveness of general practice. London: GMSC, 1985.
}

Coronary angioplasty is an alternative to aortocoronary bypass grafting for some patients with angina resistant to medical treatment. The statement agreed by the recent consensus development conference in London suggested that services for coronary artery bypass grafting should be expanded in Britain. ${ }^{1}$ Angioplasty was mentioned as a suitable form of treatment for patients with single and double vessel disease. The panel of experts thought, however, that angioplasty should undergo continued evaluation in the centres in which it had been developed before being more widely applied.

The remodelling of the lumen of diseased arteries by using coaxial dilating catheters was first reported by Dotter and Judkins in $1964 .^{2}$ The results were good, but a decade elapsed before Gruentzig developed a system for the mechanical dilatation of stenosed peripheral arteries using balloon tipped catheters introduced through the skin. ${ }^{3}$ As these balloon catheters were made smaller lesions in the proximal parts of the epicardial coronary arteries could be treated by the technique of angioplasty. ${ }^{4}$ The first percutaneous transluminal coronary angioplasty was performed by Gruentzig in Zurich in 1977, ${ }^{5}$ and since then throughout the world over 10000 patients have been treated in a similar manner. So popular has this approach become in the management of patients with angina that some observers believe that it may alter the conventional approach to their 